\title{
Podolian Melting Pot: Formation of Multicultural Community of Nobles on the Eastern Border of Polish Kingdom of the Fifteenth Century Europe
}

\begin{abstract}
The purpose of this study is to present the ways of multicultural noble community formation on the territory of Podillia (Podillya), and starting from 1434 - of Podolian voivodeship, which was the easternmost province of Polish Kingdom at the time. The research methodology follows the principles of systematizing the materials and applying interdisciplinary lenses. It utilizes a number of general methods of historical studies: historiographical, terminological, biographical, prosopographical, genealogical, and linguistic analysis. Based on the analysis of probable sites of origin of the nobles who received land assignations on the territory of Podolian voivodeship under the rule of Wtadystaw III in 1434-1444, the study traces specific regions in Polish and Czech kingdoms, from which the nobles relocated to the eastern border of Europe of that time. The main regions of the incoming to Podolian voivodeship nobles' origin include Lesser Poland, Greater Poland, Mazowia, Moravia, and Silesia. The farthest site of origin of these nobles were Moravia and Wielun district of Sieradz voivodeship in Greater Poland. The rest of the sites of origin, which can be identified, lie at the 500 to 700 kilometre distance from Podillia. For the period of the 15th century, the study differentiates several ethnic and socio-professional groups that added to the noble Podolian community. These are mercenaries, coming mostly from the territory of Czech Kingdom where the Hussite War was coming to an end at the time, who pursued noble titles by means of military service. In the middle and during the second half of the 15th century the majority of "new Podolians" settled in Podillia and already in the 2nd and 3rd generations were considered native in the local noble community. Conclusions. Determination of the probable places of origin of the nobiles incoming to the territory of Podillia in the 15th century demonstrates that they were coming from practically all the regions of the Polish Kingdom. Military people became quite a distinguished group in Podillia. The Polish king's inability to supply the military with his own subordinates made him draft people coming mostly from the Czech Kingdom. A share of them stayed in Podillia after completing their service. It is notable that at the time there was a possibility to change their social status and use the privileges granted through military service to become nobles.
\end{abstract}

Keywords: Podillia, nobility, noble community, borderland, Podolian voivodeship, mercenaries.

Regardless of their origin, class, property status, education, or specific skills, people living in medieval Europe in the $14^{\text {th }}-15^{\text {th }}$ century, for the most part, were not mobile. However, some groups could boast an extraordinary mobility by those time's standards. First of all these are people who served in the military as vassals of their masters or as mercenaries. Their mobility was very noticeable at the frontier, especially at the eastern one in Podillia. Podillia (Podillya), is a territory that emerged at a contested borderland between farming communities and nomads in the middle of the fourteenth century. Located at the very end of the route from the East to the West through which the nomads of Asia migrated to the present-day European territories of Ukraine, Hungary, Moldova, Romania, and Bulgaria, Podillia was the perfect place for nomads to choose either to move farther across the ravines covered with forests and the Carpathian Mountains, or to stay between the Dnipro (Dnieper), the Southern Buh, and the Dnister (Dniester) Rivers. This territory emerged in the historical narrative when the Lithuanian dukes and the Polish King Casimir III the Great (1333-1370) divided the legacy of the Ruthenian Kingdom and pushed the Tatars back to the steppe. Over the course of 150 years this territory passed through many dominions: as a western part of 
Golden Horde (Mongol Empire); a principality under the Koriatovych brothers; a land partitioned into several sections between the Polish king, Władysław II Jagiełło, and the grand duke of Lithuania, Vytautas; and - after 1434 - Podolian Voivodeship (the area administered by a voivode or governor) of Polish Kingdom, and Eastern Podillia as part of the Grand Duchy of Lithuania. This region became a great frontier that hosted cultural and religious diversity, and faced a continuous influx of newcomers both from the West (Germans as town residents, Polish and German nobles as beneficiaries of land rent) and the East (Armenians residing in towns, Tatars serving in the military).

Thus, who were those people that arrived at Podillia? And why do we ask this question? I will begin by answering the latter. Surveying the origin of people that came to the turbulent borderlands and became "new Podolians" enables us to demonstrate several significant, to my opinion, issues. Firstly, what region of Europe shared a border with the contested territories in the southeast? Secondly, did the contact zone become a melting pot (one of the "American-type frontiers of Europe") for all who were seeking their fortune here? Thirdly, how did living in Podillia shape local elites and bring specific features to the local noblemen, citizens, and peasants? How did the locals perceive the foreigners?

Migrations have always been caused by a number of reasons, including the following: political processes leading to a long civil war (Czech Kingdom, Golden Horde), demographic changes compelling part of the population to migrate, professional specialization of the region's inhabitants forcing them to work far from their place of residence (mercenaries). From where did they come to Podillia? An answer to this challenging question depends on one's point of view. In theory, any contested territory is a place where people come from different sides, leastways from both sides of the border imagined by those who regarded the contested area to be their own. But this is true only in theory. It seems that the communication paths and those who used them were the best advertisement that encouraged people to seek their fortune in Podillia.

The survey of the origins of noblemen's receiving landholdings in Podillia after 1434 demonstrates that they were coming to Podillia from nearly all the provinces of Polish Kingdom (see Table). The list of places also includes Silesia, from which the relatives of the settlers of the second half of the $14^{\text {th }}$ century, mainly the $1370 \mathrm{~s}-1380 \mathrm{~s}$, arrived. "The new Podolians" consisted of Moravians as well, for whom a long travel eastward was necessitated by their affiliation with the Hussite movement and the temporary cessation of the Hussite's struggle in the mid-1430s. Traditionally, Moravia was considered as one of the mercenary marketplaces in Central Europe, yet hardly did the Polish King have enough financial resources to employ them; moreover, neither Władysław III nor his entourage planned any military campaigns in Moravia ${ }^{1}$.

The mapping of the regions, from which "the new Podolians" came, demonstrates that they arrived in Western Podillia from the eastern and central provinces, except for Moravia, using communication paths, on which Lviv, Lublin, and Chełm served as transit points of this migration ${ }^{2}$.

\footnotetext{
1 The peak of his anti-Turkish policy, the campaign of 1444, ended with his defeat in Varna and the death of the young king. See more in: Jefferson J. The Holy Wars of King Wladislas and Sultan Murad: The Ottoman-Christian Conflict from 1438-1444. - Leiden; Boston, 2012. - P.357-470. On the participants from the Polish Kingdom and Podillia, in particular, see: Pentek Z. Polscy uczestnicy wyprawy warneńskiej // Balcanica Posnaniensia. - Rocz.8. 1997. - S.93-108. Among those who fought in 1444, one can see Bogdan Hynkovych, the voivode of Podillia Hrytsko Kerdei, Jan Szyszka, Krystyn of Szczuków, Michał of Buczacz, Mikołaj Domarat from Śladków, Stogniew from Szumsk, Warcisław from Daniłkowice.

2 The map of Belz szlachta's origin looks similar (Belz Voivodeship since 1462) with the only difference in the status of Belz land as the fief of Mazovia Princes, resulted in a high percentage of Mazovians among the newly arrived settlers: Janeczek J. New Authority, New Property, New Nobility: The Foundation of Noble Estates in Red Ruthenia during the Fourteenth and Fifteenth Centuries // Quaestiones Medii Aevi Novae. - Vol.7. - 2002. - P.125.
} 
Origin of Noblemen Receiving Landholdings in 1435-1444

\begin{tabular}{|c|c|c|c|c|}
\hline № & Name & Region of origin & $\begin{array}{l}\text { Destinations from } \\
\text { the places of origin } \\
\text { to Kamianets } \\
\text { (Kamyanets) }\end{array}$ & Sources \\
\hline \multicolumn{5}{|c|}{ NoBles $1435-1444$} \\
\hline 1 & $\begin{array}{l}\text { Georgiy (Jerzy) Kuncovych } \\
\text { (Kuncowicz) }\end{array}$ & - & - & $\begin{array}{l}\text { ZDM. - Cz. } .^{3} \text {. - } \\
\text { №2180. - S.5 }\end{array}$ \\
\hline 2 & Benesz from Keschcow? & - & - & $\begin{array}{l}\text { AGAD. }-\mathrm{AZ}^{4} \cdot- \\
\text { Sygn.32. }-\mathrm{S} .967\end{array}$ \\
\hline 3 & $\begin{array}{l}\text { Warcisław Wyszkowicz } \\
\text { from Daniłkowice }\end{array}$ & - & - & $\begin{array}{l}\text { BMW }^{5} \text { - Sygn.1219III. - } \\
\text { №3; ZDM. - Cz.8. - } \\
\text { №2200. - S.30-31; } \\
\text { №2449. - S.255-256 }\end{array}$ \\
\hline 4 & Mroczek from Krasów & $\begin{array}{l}6 \text { places named Krasów } \\
\text { (Krasov) in Silesia, } \\
\text { Mazovia, Lublin, Volhynia } \\
\text { Lands and Sandomierz }\end{array}$ & - & $\begin{array}{l}\text { AGAD. - AZ. - } \\
\text { Sygn.32. - S.967-968 }\end{array}$ \\
\hline 5 & $\begin{array}{l}\text { Jan Wywier from } \\
\text { Kurzeszyn }\end{array}$ & Rawa district & $\sim 700 \mathrm{~km}$ & $\begin{array}{l}\text { ZDM. - Cz.8. - №2186. - } \\
\text { S.13-14; №2204. - S.34 }\end{array}$ \\
\hline 6 & $\begin{array}{l}\text { Shyshka Lambanch } \\
\text { (Schischka Lambancz in } \\
\text { sources) }\end{array}$ & Possibly Silesia & - & $\begin{array}{l}\text { ZDM. - Cz.8. - } \\
\text { №2187. - S.14 }\end{array}$ \\
\hline 7 & Jan Słabosz & - & - & $\begin{array}{l}\text { ZDM. - Cz.8. - №2188. - } \\
\text { S.15 }\end{array}$ \\
\hline 8 & $\begin{array}{l}\text { Domarat from Śladków } \\
\text { (district writer) }\end{array}$ & Łęczyca district & $\sim 770 \mathrm{~km}$ & $\begin{array}{l}\text { ZDM. - Cz.8. - №2190. - } \\
\text { S.16; №2244. - S.70-71; } \\
\text { №2361. - S.174; } \\
\text { №2362. - S.175-176 }\end{array}$ \\
\hline 9 & $\begin{array}{l}\text { Jan Fiol from Konary } \\
\text { (Konarów) }\end{array}$ & $\begin{array}{l}\text { Possibly Krakow voivode- } \\
\text { ship }\end{array}$ & $\sim 600 \mathrm{~km}$ & $\begin{array}{l}\text { ZDM. - Cz.8. - №2201. - } \\
\text { S.31-32 }\end{array}$ \\
\hline 10 & Ivan from Bagovytsya & Podillia & - & $\begin{array}{l}\text { ZDM. - Cz.8. - №2202. - } \\
\text { S.32-33; №2231. - S.136 }\end{array}$ \\
\hline 11 & Jan from Janowice & - & - & $\begin{array}{l}\text { ZDM. - Cz.8. - №2211. - } \\
\text { S.39-40 }\end{array}$ \\
\hline 12 & Sen'ko from Verbovets & Podillia & - & $\begin{array}{l}\text { ZDM. - Cz.8. - №2213. - } \\
\text { S.41-42 }\end{array}$ \\
\hline 13 & Petro from Bagovytsya & Podillia & - & $\begin{array}{l}\text { ZDM. - Cz.8. - - №2214. - } \\
\text { S.42-43; №2215. - S.43-44 }\end{array}$ \\
\hline 14 & Mikołaj from Wierzbica & $\begin{array}{l}4 \text { places named Wierzbica } \\
\text { in Radom, Chełm, Płock, } \\
\text { Lublin, Wiślica districts }\end{array}$ & - & $\begin{array}{l}\text { ZDM. - Cz.8. - №2227. - } \\
\text { S.56-57 }\end{array}$ \\
\hline 15 & Sędziwój Gosieński & - & - & ZDM. -Cz.8. - №2228. -S.57 \\
\hline 16 & $\begin{array}{l}\text { Jan Słabosz from Tarnów } \\
\text { and Kawęczyn }\end{array}$ & $\begin{array}{l}\text { More than } 20 \text { Kawezczyns } \\
\text { in Polish Kingdom }\end{array}$ & - & $\begin{array}{l}\text { AGAD. - Tzw. ML } \text { ML. }^{6} \\
\text { Dział IV B. - Sygn.17. - } \\
\text { K.183-183 v; ZDM. - } \\
\text { Cz.8. - №2245. - S.71; } \\
\text { №2323. - S.137-138 }\end{array}$ \\
\hline 17 & $\begin{array}{l}\text { Bylina from Lubnicz } \rightarrow \\
\text { Dzietrzkowice }^{7}\end{array}$ & Wieluń district & $\sim 800 \mathrm{~km}$ & $\begin{array}{l}\text { AGAD. - AZ. - Sygn.32. - } \\
\text { S.935, 969; ZDM. - Cz.8. - } \\
\text { №2419. - S.222 }\end{array}$ \\
\hline 18 & $\begin{array}{l}\text { Wojciech Szostek from } \\
\text { Dzietrzkowice } \\
\text { (castle judge in Kamianets } \\
\text { in 1440) }\end{array}$ & Wieluń district & $\sim 800 \mathrm{~km}$ & $\begin{array}{l}\text { ZDM. - Cz.8. - №2240. - } \\
\text { S.67; №2259. - S.82 }\end{array}$ \\
\hline
\end{tabular}

${ }^{3}$ Zbiór dokumentów małopolskich (ZDM). - Cz.8: Dokumenty z lat 1435-1450. Uzupełnienie: dokumenty z lat 1286-1442 / Wyd. I.Sułkowska-Kuraś, S.Kuraś. - Wrocław; Warszawa; Kraków; Gdańsk, 1975.

${ }^{4}$ Archiwum Zamoyski w AGAD.

5 Biblioteka miejska i wojewódzka w Bydgoszczy.

6 Tak zwana Metryka Litewska w AGAD.

7 Słownik historyczno-geograficzny ziemi wieluńskiej w średniowieczu / Wyd. R.Rosin. - Warszawa, 1963. - S.76, 108.

Український історичний журнал. - 2020. - №4 


\begin{tabular}{|c|c|c|c|c|}
\hline 19 & Ivan from Stepankivtsi & Podillia & & $\begin{array}{l}\text { ZDM. - Cz.8. }- \\
\text { №2241. - S.68 }\end{array}$ \\
\hline 20 & Borsz from Kocina & Wiślica district & $\sim 550 \mathrm{~km}$ & $\begin{array}{l}\text { ZDM. - Cz.8. - №2242. - } \\
\text { S.69; №2274. - S.94 }\end{array}$ \\
\hline 21 & $\begin{array}{l}\text { Jan Szyszka (Iohannes } \\
\text { Schiska in sources) }\end{array}$ & Possibly Silesia & - & $\begin{array}{l}\text { ZDM. - Cz.8. - } \\
\text { №2243. - S.69-70; } \\
\text { №2468. - S.269-270 }\end{array}$ \\
\hline 22 & Piotr Ciołek from Kłodnica & Lublin district & $\sim 520 \mathrm{~km}$ & $\begin{array}{l}\text { ZDM. - Vol.8. - №2291. - } \\
\text { S.111-112 }\end{array}$ \\
\hline 23 & $\begin{array}{l}\text { Jan Kiemlicz from } \\
\text { Włostowice (now part city } \\
\text { Puławy }^{8} \text { ) }\end{array}$ & Lublin district & $\sim 530 \mathrm{~km}$ & $\begin{array}{l}\text { ZDM. - Cz.8. - } \\
\text { №2305. - S.121 }\end{array}$ \\
\hline 24 & Mach from Podlachia & Podlachia & - & $\begin{array}{l}\text { AGAD. - AZ. - } \\
\text { Sygn.32. - S.935; ZDM. - } \\
\text { Cz.8. - №2367. - S.179 }\end{array}$ \\
\hline 25 & Sigismund Kierdey & $\begin{array}{l}\text { Golden Horde, (Ruthenian } \\
\text { lands since 1360th) }\end{array}$ & - & $\begin{array}{l}\text { AGZ. - T.5. - №87. - } \\
\text { S.110 }\end{array}$ \\
\hline 26 & Krystyn from Szczuków & Lesser Poland, Silesia & - & $\begin{array}{l}\text { ZDM. - Cz.8. - } \\
\text { №2357. - S.170-171; } \\
\text { №2448. - S.253-254 }\end{array}$ \\
\hline 27 & Stanko (Stanek) & - & - & $\begin{array}{l}\text { ZDM. - Cz.8. - } \\
\text { №2369. - S.180 }\end{array}$ \\
\hline 28 & Václav Spisz from Sobáčov & Moravia & $\sim 880 \mathrm{~km}$ & $\begin{array}{l}\text { ZDM. - Cz.8. - №2384. - } \\
\text { S.193-194 }\end{array}$ \\
\hline 29 & Jan from Chomentów & $\begin{array}{l}\text { Possibly Mazovia, Kujawy } \\
\text { or Greater Poland lands }\end{array}$ & - & $\begin{array}{l}\text { ZDM. - Cz.8. - №2386. - } \\
\text { S.195-196 }\end{array}$ \\
\hline 30 & $\begin{array}{l}\text { Mikołaj Podolec from } \\
\text { Grodków }\end{array}$ & $\begin{array}{l}\text { Possibly Mazovia, } \\
\text { Wyszogród district }\end{array}$ & $\sim 720 \mathrm{~km}$ & $\begin{array}{l}\text { ZDM. - Cz.8. - №2392. - } \\
\text { S.199-200 }\end{array}$ \\
\hline 31 & $\begin{array}{l}\text { Mytko Zarubych from } \\
\text { Lysets }\end{array}$ & Podillia & - & $\begin{array}{l}\text { ZDM. - Cz.8. - №2425. - } \\
\text { S.226-227 }\end{array}$ \\
\hline 32 & $\begin{array}{l}\text { Lukasz Lojowicz from } \\
\text { Milejowce }\end{array}$ & $\begin{array}{l}\text { Possibly Radom or } \\
\text { Opatów districts }\end{array}$ & - & $\begin{array}{l}\text { ZDM. - Cz.8. - №2426. - } \\
\text { S.227-229 }\end{array}$ \\
\hline 33 & Stanisław from Bedrykovtsi & $\begin{array}{l}\text { Silesia (Podillia since } \\
\text { 1380th) }\end{array}$ & - & $\begin{array}{l}\text { ZDM. - Cz.8. - №2427. - } \\
\text { S.229-300 }\end{array}$ \\
\hline 34 & Tomasz from Hynkovtsi & - & - & $\begin{array}{l}\text { AGZ. - T.6. - №20. - } \\
\text { S.31-32 }\end{array}$ \\
\hline 35 & $\begin{array}{l}\text { Ignat Neshevych from } \\
\text { Benankovtsi }\end{array}$ & Possibly Podillia & - & $\begin{array}{l}\text { ZDM. - Cz.8. - №2430. - } \\
\text { S.233-234 }\end{array}$ \\
\hline 36 & San’ko Kozlovsky & Possibly Podillia & - & $\begin{array}{l}\text { ZDM. - Cz.8. - №2431. - } \\
\text { S.234-235 }\end{array}$ \\
\hline 37 & $\begin{array}{l}\text { Ivan Sen'ko from } \\
\text { Verkhovest }\end{array}$ & Possibly Podillia & - & $\begin{array}{l}\text { ZDM. - Cz.8. - №2434. - } \\
\text { S.237-238 }\end{array}$ \\
\hline 38 & $\begin{array}{l}\text { Mikołaj Widinicz from } \\
\text { Słabicz }\end{array}$ & - & - & $\begin{array}{l}\text { AGAD. - AZ. }- \\
\text { Sygn.32. - S.973 }\end{array}$ \\
\hline 39 & Stogniew from Szumsk & Mazovia land & $\sim 760 \mathrm{~km}$ & $\begin{array}{l}\text { ZDM. - Cz.8. - №2446. - } \\
\text { S.251-252 }\end{array}$ \\
\hline 40 & Steczko from Włodowice & $\begin{array}{l}\text { Possibly Włodowice on } \\
\text { Silesian and Lesser } \\
\text { Poland borderland }\end{array}$ & $\sim 700 \mathrm{~km}$ & $\begin{array}{l}\text { ZDM. - Cz.8. - №2461. - } \\
\text { S.264-265 }\end{array}$ \\
\hline 41 & Stanisław from Rudnik & - & - & $\begin{array}{l}\text { AGAD. - AZ. - } \\
\text { Sygn.32. - S.975 }\end{array}$ \\
\hline 42 & $\begin{array}{l}\text { Mikołaj Domarat from } \\
\text { Dobrzyń, possibly, a relative } \\
\text { of Domarat from Sladków }\end{array}$ & $\begin{array}{l}\text { More than } 10 \text { Dobrzyńs in } \\
\text { Polish Kingdom }\end{array}$ & - & $\begin{array}{l}\text { ZDM. - Cz.8. - №2466. - } \\
\text { S.268-269 }\end{array}$ \\
\hline 43 & Bogdan Hynkowycz & - & - & $\begin{array}{l}\text { ZDM. - Cz.8. - } \\
\text { №2495. - S.299 }\end{array}$ \\
\hline
\end{tabular}

${ }^{8}$ Słownik historyczno-geograficzny województwa lubelskiego w średniowieczu / Wyd. S.Kuraś // Dzieje Lubelszczyzny. - T.3. - Warszawa, 1983. - S.263-264. 
As seen in Table, Moravia was one of the most distant regions of "the new Podolians" origin, a distance of around 880 kilometres, whereas most of the places were 500-700 kilometres away from Podillia, which is also a very long distance at that time.

Finally, there was another, eastern side of the contested territories. Although the migration from the Tatar side to the Podolian Voivodeship was not so noticeable, it cannot be neglected. Already mentioned more than once, the Kerdei family, part of which settled in Podillia, could serve as an example and a model for those who wished to serve the Polish King. Political changes in the Black Sea steppe occurred in part due to the impact of Grand Duchy of Lithuania and led to the emergence of Crimean Khanate in the $1440 \mathrm{~s}^{9}$. That time became a turning point for many inhabitants of the steppe and a moment when they, especially the elites, had to decide who to serve and pledge their loyalty. The need to choose, in turn, influenced the number of natives coming from the Tatars in the eastern provinces of Kingdom of Poland. Although they are not seen, except for the Kerdeis, among the recipients of the king's landholdings and other land transactions in the second half of the $15^{\text {th }}$ century ${ }^{10}$, yet they should not be disregarded. Later, in the $16^{\text {th }}$ century, their descendants would be present in the lists of guard squadrons, in which they would play an important role thanks to their experience and skills in confronting the raids from the opposite side of the alleged border. The name of one of the suburbs of the city of Bar, Bar-Chemeryskyi, eloquently indicates that chemerysy, that is, the inhabitants of the steppe, as the local population called them, used to live there. However, this would be a story of the subsequent $16^{\text {th }}$ century.

According to the sources available, in the first half of the $15^{\text {th }}$ century, the nobility corporation of Podillia consisted mostly of newcomers from various provinces of Polish Kingdom, Silesia, and Moravia. They left their places of settlement because of political changes, especially in Czech Kingdom that included Moravia and Silesia. The gradual "appearance" of the local Ruthenians in the sources was not numerous, yet it should not be ignored. The new law and land titles documentation culture slowly became a part of everyday life, which explains why other recipients of the king's landholdings in Podolian Voivodeship outnumbered the locals and Ruthenians. The raids of the Tatars were also one of the critical factors, which became a permanent feature of Podillia's everyday life since the 1440 s, influencing almost every family.

\section{Military Service}

The most efficient way to become a "new Podolian" was military service. The overview of families holding official positions and the noblemen who received titles to land during the reign of Casimir IV (1447-1492) ${ }^{11}$ reveals a few new names, since at the dawn of the early modern period the nobility was a completely established community with its place in the societal hierarchy. At first glance, this community appeared to be rigidly stratified, but it was open to new members. It was the military men guarding the border who used this opportunity first. The enlargement of the

9 Tyszkiewicz J. Tatarzy na Litwie i w Polsce: Studia z dziejów XIII-XVIII w. - Warszawa, 1989. - S.130-131.

${ }_{10}$ Михайловський B. Надання земельної власності у Подільському воєводстві за Казимира IV // Записки Наукового товариства імені Шевченка. - Т.251. - Л., 2006. - С.399-438.

11 For the land titles see: Там само. - C.399-438. 
Podolian nobility by way of accepting new members from the outside began slowly with the soldiers when Polish Kingdom launched a guarding service of its eastern border after the end of the thirty-year war with Teutonic Order. Until the second half of the $15^{\text {th }}$ century, Podolian Voivodeship had been a certain land reserve for rewarding people who deserved appreciation (participants of the "Lutsk War", antiTurkish campaigns of Władysław III), but later the possibilities for such rewards decreased significantly. Therefore, military service remained to be one of the possible ways to make connections to this region not through the king' favour but through marrying into local families.

The emergence of the first lists of the noblemen serving in the border patrol service since the $1470 \mathrm{~s}^{12}$, and availability of their last names in the later documents designated as Podolian noblemen proved that they established their connections in Podillia in different ways: by receiving land titles, marrying into local families, carrying out administrative service, and holding government positions such as the Starosta General of Kamianets. All these factors contributed to the evolution of "the new Podolians". These lists are filled with names of gentry and settlers not only from other regions of Polish Crown but also from other countries. Some of them were attributed as podolita (Podolian), for instance, Kuropatva, Krczonowski, or some Khanych $^{13}$.

A distinguishing feature of that time was the military service of young noblemen from wealthy families, whose relatives had held or were holding the high-ranking offices in Podolian and Ruthenian Voivodeships. The list of Krakow Standard-bearer (chorazy) Firlei from Dabrowica's squadron, copied in Lviv on February 15, 1499, mentioned Voivodych of Podillia Jan, probably Jan of Buczacz, the son of Jakub ${ }^{14}$.

Since 1492, there are annual lists of squadron heads and squadrons located in Podillia. One of the first lists shows the following names and nicknames of the officers: Dersław (Derslao), Janusz Świerczowski (Janusch Swirczowsky), Hynek (Hynek), Petro Loncky (Petro Lanczky), Jankowsky (Jankowsky) та Jan Jurkowsky (Yurkovsky) (Iohanni Jukowsky) and 1022 cavalrymen in total ${ }^{15}$. In 1493 in Piotrków, the king recruited Jan Świerczowski along with 206 cavalrymen and Hynek Uneńsky and

\footnotetext{
${ }^{12}$ Ludwig Kolankowski notes that the first squadron heads were recorded in 1479: Kolankowski L. Roty koronne na Rusi i Podolu 1492-1572 r. // Ziemia Czierwińska. - T.1. - №2. - Lwów, 1935. - S.1. (Numbering from a separate printout). The list of the first squadron heads includes Myszkowsky de Przeczyzow, who was probably the future Ruthenian Starosta General Piotr Myszkowski: Matricularum Regni Poloniae summarus, excussis codicibus, qui in Chartophylacio Maximo Varsoviensi asservantur. - Pars 1: Casimiri IV regis tempora complectens (1447-1492) / Ed. T.Wierzbowski. - Warszawa, 1905. - №1486. Though, Konstanty Górski provided the lists of squadrons in 1471 and 1474 in an annex to his research: Górski K. Historia jazdy polskiej. Kraków, 1894. - S.271-274. In 1479, Squadron head Myszkowski received money for his squadron: Archiwum Główne Akt Dawnych w Warszawie (AGAD). - Archiwum Skarbu Koronnego (ASK). - Dz.85. - Syng.1. - K.53, 54-54 v.; Samsonowicz H. Rota Piotra Storkowskiego z 1477 r. // Acta Universitatis Nicolai Copernici: Historia. T.26(240). - Toruń, 1992. - S.157-162.

13 AGAD. - ASK. - Dz.85. - Sygn.6. - K.219, 220; Sygn.11. - K.33.

14 Listy i akta Piotra Myszkowskiego generalnego starosty ziem ruskich króla Jana Olbrachta spisane przez ś. p. Adolfa Pawińskiego / Wyd. A.Lewicki. - Kraków, 1898. - №20. - S.24. The list presents a range of military szlachta: „Slywka, Smolka, Johannes Podolszky woyewodzycz, Petrus Kola, Nicolaus Gyemyelnyczky, Nicolaus Zolkyewszky, Joannes Doluszky, Petrus Gnynszky, Hynek, Stanislaus, Simon Chlyevyczky, Beneszch, Woyczyech Sapoleyenszky, Januszchowszky, Lonyvszky, Wronykowszky, Jan Hladky, Bernath Moravyczky, Jakub Kroczowszky, Waczlaw Vyelky, Prusz Jan, Beranet, Caspar Ungarius, Thomaszch Charcawth, Benedict Charwath, Kothowsky”.

${ }_{15}$ Matricularum Regni Poloniae Summaria (MRPS). - Pars 2: Iohannis Alberti regis tempora comlectens (1492-1501) / Ed. T.Wierzbowski. - Warszawa, 1907. - №33.
} 
Jankowsky with squadrons of 170 persons each ${ }^{16}$. In the same year, Janusz Świerczowski received money in Poznań for the service of 212 cavalrymen: 10 Hungarian florins for each of them for three months ${ }^{17}$. At the same time, the squadrons of Jankowsky, Petro Loncky, Hynek, Dersław, and Żukowski were also mentioned in Poznan ${ }^{18}$. In 1494, Jakub Pukowski was recruited with 100 cavalrymen $^{19}$. Two of the aforementioned heads of squadrons, Janusz Świerczowski (the Świerczowskis were recorded in Podillia in the late $14^{\text {th }}$ century) ${ }^{20}$ and Hynek (from Łęnczyca Voivodeship) were linked with Podillia. Janusz Świerczowski reached the highest point of his career in the next century, holding the position of the Starosta of Terebovlya in 1507-1526 ${ }^{21}$.

Members of the family from Buczacz and the family from Chodcza were also listed among the squadron heads and soldiers. In 1501, Voivodych of Podillia Jan of Buczacz had a squadron of 200 cavalrymen; Stanislaw of Chodcza, Castellan of Lviv, the starosta of Kamianets and Lviv had a squadron of 300 cavalrymen, and his brother Piotr, the Starosta of Halych - 150 cavalrymen $^{22}$. The foreigners might have come here to serve because of mobilization for levy en masse (one of the last at that time) in 14971498, caused by Jan I Olbracht's invasion of the kingdoms of Moldavia and Walachia ${ }^{23}$. The campaign involved a lot of nobility from all over Polish Crown and catalysed turmoil on the south-eastern border of the kingdom. The King lost the campaign, thus provoking a Turkish campaign in response. The latter demonstrated the inability of levy of mass along with a few military units to resist a well-organized and experienced Turkish army.

Tatar units, in their turn, more actively began to disturb the borderland regions, and no longer limited themselves to raiding the Podolian Voivodeship ${ }^{24}$, but reached all the way to the boundaries of Belz Voivodeship ${ }^{25}$. The Tatar raids were mentioned in the letters of Piotr Myszkowski from the summer of 1499, who was appointed by the king to guard the border "for defending the Ruthenian lands and the starosta general's constituencies" (...pro defensione terrarum Russie in capitaneum generalem constituentes ${ }^{26}$. The turmoil on the border demanded a significant number of warriors and the maintaining of the practice of posting the noblemen in residence in Podillia that had been introduced at the beginning of the $15^{\text {th }}$ century.

\footnotetext{
16 Ibid. - №166.

17 Ibid. - №199, 236.

18 Ibid. - №200, 238.

19 Ibid. - №369.

${ }^{20}$ Janusz Świerczowski probably had no links to Podillia, since he and Bartolomei were called courtiers of Grand Duchy of Lithuania (Iohanni et Bartolomeo Szwirczowsky curiensibus illustrissimi magni ducis Lithuaniae...) during the Moldavian campaign of Jan I Olbracht in 1497: Materiały do dziejów pospolitego ruszenia z lat 1497 i 1509 : Zebrane w części przez Adolfa Pawińskiego // Archiwum Komisyi Historycznej. - T.9. - Kraków, 1902. - №209. S.290.

${ }^{21}$ Urzędnicy województwa ruskiego XIV-XVIII w.: Spisy / Opr. K.Przyboś. - Wrocław, 1987. - №672. - S.97.

22 MRPS. - Pars 2. - №1465, 1501-1502.

${ }^{23}$ Fac L. Turecka wyprawa odwetowa na terenach Rusi Czerwonej w roku 1498: Zarys problem // Roczniki Przemyski. - T.41. - №1: Historia wojskowości. - 2005. - S.3-26.

${ }^{24}$ On 7 August 1498 Kamianets and Skala received the tax exemption for 15 years to prevent impoverishment: MRPS. - Pars 2. - №1267-1268. The next year, the king abolished customs duties for citizens of Kamianets, which was probably caused by a military threat: Ibid. - №1371.

${ }_{25}$ The letter of the Starosta of Belz Jan Kamieniecki, written on 20 July, 1499, to King Jan I Olbracht concerning the raid of Tatars in the suburbs of Busk that was not repelled because of the lack of people and poor preparedness of noblemen: Listy i akta Piotra Myszkowskiego. - №26. - S.30-31.

${ }^{26}$ Ibid. - №21. - S.24-25. The letter of Piotr Myszkowski to the King, written on 23 July 1499.
} 
It should be pointed out that to live on the turbulent Christian-Muslim border was a common practice in medieval and early modern Europe. The Iberian Peninsula, where Emirate of Granada existed till the end of Middle Ages, witnessed a related situation. The fear of being captured forced the local population to acquire peculiar skills of living in a permanent state of war or rather dealing with a war threat ${ }^{27}$. The Iberian Peninsula was a place where one could lose everything in a moment - or could achieve a social advance or simply get rich. These peculiarities hardly differed from those in Podillia. However, the latter has never witnessed the crusades against the Muslims, although propaganda transformed Podillia into European antemurale christianum.

The organization of Current Defence (obrona potoczna) to guard the borders of Polish Kingdom in the second half of the $15^{\text {th }}$ century was a milestone in the history of Podillia, as the region became a place of military service, where the Crown noblemen not only acquired military skills but also - and what is very important - got acquainted with each other. Military service was a way of socialization and entering in the noble circles, provided marriage and social contacts opportunities for the lower- and middlerange gentry who were not allowed to participate in the Crown Sejms, and contributed to advancing their military and administrative careers.

\section{Mercenaries from Czech Kingdom in Podillia in the 15th Century}

At the beginning of the subchapter, it has been stated that some part of "the new Podolians" came from the West, Czech Kingdom in particular. They were, first of all, mercenaries from Czech Kingdom, Silesia, and Moravia in particular. The appearance of mercenaries from Silesia and Czech land, where Kingdom of Poland had been hiring mercenaries since the beginning of the $15^{\text {th }}$ century, among the squadron heads in Podillia ${ }^{28}$ was a typical situation due to an excess of skilled people in Central Europe ${ }^{29}$. Their numbers increased after the end of the Hussite movement in Czech land ${ }^{30}$. According to the calculations of Tadeusz Grabarczyk, 25 percent of all squadron heads of infantry in Polish Kingdom in 1454-1500 were from Czech Kingdom and Silesia ${ }^{31}$. Considering infantry, 540 Silesians and 471 Czechs served with the troops of Polish King during the same period, constituting 15 percent of a total number recorded in sources. Their share was probably higher, as Grabarczyk has not identified 4650 of 6966 persons $^{32}$.

\footnotetext{
${ }^{27}$ Malinowski $M$. Najnowsza historiografia hiszpańska na temat pogranicza chrześcijańsko-muzułmańskiego na półwyspie Iberyjskim w XIII-XV w. // Acta Universitatis Lodziensis: Folia Historica. - T.72: Studia z historii Polski i powszechnej XIII-XVIII w. - Łódź, 2001. - S.38-39.

${ }^{28}$ In 1481, one of the squadron heads was Zolna Czech (Zolna cum Czech): AGAD. - ASK. - Dz.85. - Sygn.1. - K.72. The list of the squadron in 1497 indicated that soldiers had arrived from Wrocław, Brzeg, Opole, Legnica, Głogów, etc.: Ibid. - Sygn.2. - K.109-112. For instance, Silesian squadron heads served in Podillia in 1493 (et etiam pro Slesier rotmagistris): MRPS. - Pars 2. - №265.

${ }^{29}$ Hant J., Carlson U. Mercenaries in Medieval and Renaissance Europe. - McFarland, 2013. - P.130; Grabarczyk T. Jazda zaciężna Królestwa Polskiego. - Łódź, 2015. - S.15.

${ }^{30}$ Betts R.R. Social and Constitutional Development in Bohemia in the Hussite Period // Past \& Present. - №7. 1955. - P.49.

${ }^{31}$ Grabarczyk T. Piechota zaciężna Królestwa Polskiego w XV w. - Łódź, 2000. - S.69.

32 Ibid. - S.75.
} 
Due to the long-lasting conflict in Czech Kingdom in the first half of the $15^{\text {th }}$ century $^{33}$, the region had a lot of experienced war professionals seeking new service opportunities. Polish Kingdom constantly felt shortages of skilled personnel for military service at the border and faced the need for lower and middle-level officers, as well as ordinary soldiers. The King was not able to meet the shortage with his own resources. The primary sources demonstrate a certain dependence on mercenaries from Czech Kingdom, Moravia, and Silesia, releasing a significant number of soldiers after the end of the conflict between the Hussites and Empire, as evidenced by Czech units guarding Teutonic Order's cities during the thirteen-year war between Polish Kingdom and Teutonic Order (1453-1466) ${ }^{34}$.

The sources indicate a significant number of persons with names and patronymics marking them as those who arrived from the aforementioned territories: Jan Moravčík (Joannes Morawczyk) served in Peremyshl in the late $15^{\text {th }}$ century ${ }^{35}$, Bernat Moravski (Bernath Morauyczky) and Václav Velký (Waczlaw Vyelky) from Firley's squadron ${ }^{36}$, Mikláš Lahetka (Miklasth Lachetka) and Martin Čech (Marcicz Czech) from the Piotr Storkowski's squadron ${ }^{37}$. The list of squadron heads whose squadrons possessed firearms also includes mercenaries from that region: Jiří Kalus (Irzyk Kałusz), Jan Kalus (Jan Kałusz), Hans Scholc (Hanusz Szolc), Jiří Homutovsky (Irzyk Chomutowski), Jiří Mundry (Irzyk Mundry), Jiří Hubaty (Irzyk Hubaty), Matias Moravchyk (Matysz Morawczyk), and perhaps Sokol Slovacky (Sokót Stowacki) ${ }^{38}$. Mercenaries from that multi-ethnic region were not a novelty in Podillia, as Silesians and Czechs had been recorded here since the second half of the $14^{\text {th }}$ century, e. g. Bedrych from Bedrychovci, Krystyn Szczukowski, and others.

Written on July 27, 1499, two letters from commanders of infantry regiments to King Jan I Olbracht illustrate that mercenaries from Czech Kingdom, Moravia, and Silesia served in Podillia. The first letter was written in the Old Czech language. Assigned to obtain money from the king, Jan Kalus might have been a local (as the settlement of Kalus has existed in Podolian Voivodeship since the $13^{\text {th }}$ century), though he is recorded as Johannes Kalwsch in another document, which can serve as evidence of his German origin. The letter mentioned the squadron head Jiří Homutovski (Girzik Chomutowski), who was apparently from the Czech lands ${ }^{39}$. Jan Kalus was probably ennobled in 1505, joining the Ciołek family of arms, the adjusted version of which

\footnotetext{
${ }^{33}$ For example: Kaminsky H. A History of the Hussite Revolution. - Berkeley, 1967; Klassen J. The nobility and the making of the Hussite Revolution. - Boulder, New York, 1978.

${ }_{34}$ Dlugosii I. Annales seu Cronicae Incliti Regni Poloniae, Liber 12: 1445-1461 / Ed. K.Baczkowski etc. - Warszawa, 2003. - P.206-207, 236-237, 274-276.

35 Listy i akta Piotra Myszkowskiego. - №24. - S.28. In the 1501 letter of Cardinal Frederik, Moravčík and Hynek were described as a later cardinal Fredyryks rothmagistri societas vestre: Ibid. - №75. - S.76.

36 Ibid. - №20. - S.24.

37 Samsonowicz H. Rota Piotra Storkowskiego z 1477 r. - S.160.

38 Grabarczyk T. Firearms in the equipment of mercenary troop of the Kingdom of Poland in 1471-1500 // Fasciculi Archeologiae Historicae, Recent Research into Medieval and Post Medieval Firearms and Artillery. - Vol.25. - Łódź, 2012. - P.57.

${ }^{39}$ Listy i akta Piotra Myszkowskiego. - №32. - S.37-38. The following persons witnessed the document: Girzik Chomutowsky rothmistr, Ambroz rothmistr, Jan Sokolowsky rothmistr, Stefek rothmistr y gyny wssichchi desatniczy a strzielczy piessy na Kamienczy (Ibid. - №32. - S.38; №34. - S.39). Probably, it was the same Jan Kalus enlisted by Jan I Olbracht in Sandomierz on 27 October 1500, along with his rota of 200 infantrymen: Ibid. - №73. - S.74. In the list under the year 1497, he was recorded as Calusch: AGAD. - ASK. - Dz.85. - Sygn.2. K.124.
} 
included the phrase that he was from the Hungarian city of Brod (nob. Ioanni Calusch de Brod, civitate regni Hungariae ${ }^{40}$.

The second letter, signed by sergeant Jan Sokolovský from Lukasz's squadron, was also written in Old Czech concerning a squadron head's corruption ${ }^{41}$. Although there are some doubts regarding the origin of the squadron heads, the scrivener who wrote the letters was undoubtedly from Czech lands, because even the theory of undefined Polish language in the late $15^{\text {th }}$ - early $16^{\text {th }}$ century cannot explain the Czech expressions Nayiasnieyssy kraly..., ...wassi kralowske. Moreover, the confirmation that these persons from Silesia, Moravia, or Czech Kingdom resided in Kamianets and wrote these documents, are the mentions of the Kamianets city scrivener Václav in $1510^{42}$.

In 1500, a Silesian Mikołaj Sle(n)zhak (Nicolaus Slezak) received Bedrychovtsi and Vyselok as collateral from Andrzej from Novodvor, as witnessed by the Starosta General of Kamianets Stanisław of Chodcza ${ }^{43}$. It seems weird that this family estate was pledged. However, it might indicate that the Świerczes lost their positions among the middle-class nobility of Podolian Voivodeship, which they had gained during their office of the Castellan of Kamianets in the second half of the $15^{\text {th }}$ century. It is noteworthy that both the Swierczes and Mikołaj Sle(n)zhak were from Silesia, this their shared Silesian origin could serve as an additional favourable argument to make a deal.

Thus, Silesia, Moravia, and Czech Kingdom were the most distant regions (no lesser than $800 \mathrm{~km}$ ), from which people migrated to Podillia seeking their fortune. To them, a service in the military units was the first step to settling here. Therefore, Podillia was a certain "melting pot", in which the locals and people from both sides of the alleged border were mixing and forming a Podolian community in the broader sense. The regional assimilation affected all the strata, but only nobility, unfortunately, could be analysed from this perspective.

The formation of the border on the boundaries of contested territories ended, most likely, in the mid-15 ${ }^{\text {th }}$ century when the rivalry between Kingdom of Poland and Grand Duchy of Lithuania regarding the ownership of Podillia came to an end. The partitioned Podillia was organized in two provinces. Bratslavshchyna, its eastern part, was such an uncertain territory without definite borders that we know almost nothing about the events that occurred there. Podolian Voivodeship, the western part of Podillia, became the easternmost province of Polish Kingdom. This part was wholly integrated into Polish Crown and its law, which, along with military units for protecting the border in the second half of the $15^{\text {th }}$ century, were the main factors

\footnotetext{
${ }^{40}$ Trelińska B. Album armorum nobilium Regni Poloniae XV-XVIII saec: Herby nobilitacji i indygenatów XVXVIII w. - Lublin, 2001. - №48. - S.59.

${ }^{41}$ Listy i akta Piotra Myszkowskiego. - №33. - S.38.

${ }_{42}$ The letter of Sigismund I the Old to the Starosta of Kamianets Stanisław Lanckoroński, written on November 3, 1510: Acta Tomiciana / Ed. A.T.Działyński. - T.1: 1507-1511. - Poznań, 1852. - №136. - P.121 “...per Vatzlav, notarium castrensem...”. Once again, Scrivener Václav (Venceslaum notarius) was mentioned in the king's letter to Jan Tworowski on February 19, 1511: Ibid. - №181. - P.145. During the gathering of troops in Medzhybizh, in 1513, 1513 p., Scrivener Václav (Venceslaus notari[us]) was recorded after Jan Tworowoski: AGAD. - ASK. - Dz.85. Sygn.12. - K.43v, 44v, 97.

${ }^{43}$ Putaski K. Stare osady w ziemie kamienieckiej i dziedziczące na nich rody podolskiej szlachty historycznej // Idem. Szkice i poszukiwania historyczne: Serya 3. - Kraków, 1906. - P.153-155.
} 
in the formation of the local nobility corporation. Openness to new rules and new members was a distinguishing feature of the Podolian nobility (it applies only to the local Ruthenians).

Settlers from almost every land of Polish Kingdom became "the new Podolians" (see Table). Military officers constituted a prominent group in Podillia at that time. The organization of border defence regiments required a permanent location of military units in the Podolian Voivodeship. The Polish King was not able to form them using his subjects only, so he hired people from Czech Kingdom. Some part of these mercenaries settled in Podillia after the end of their service. Since the mid-16 ${ }^{\text {th }}$ century, citizens could change their social status and become ennobled after performing military duties. Their birthplaces, which sometimes were $500-800 \mathrm{~km}$ from Podillia, is a vivid illustration of the late medieval imaginary geography showing which European regions chose contested territories between Dnister and Dnipro Rivers to seek a better fortune or earn money.

The Podolian Voivodeship was a multicultural region on the contested borderlands, where Ruthenians used to live with Poles, Hungarians, Armenians, Valachians, and Germans. The primary sources mention mainly "the new Podolians", distorting the broader picture of the Podolian society of that time. However, they demonstrate that Podillia was not a typical region among the Ruthenian lands of Polish Crown and Grand Duchy of Lithuania.

\section{REFERENCES}

1. Betts, R.R. (1955). Social and Constitutional Development in Bohemia in the Hussite Period. Past \& Present, 7, 37-54.

2. Dlugosii, I. (2003). Annales seu Cronicae Incliti Regni Polonie, Liber 12: 1445-1461. ed. Krzysztof Baczkowski etc. Kraków: Akademia Umiejẹtności. [in Latin].

3. Fac, L. (2005). Turecka wyprawa odwetowa na terenach Rusi Czerwonej w roku 1498: Zarys problem. Roczniki Przemyski, 41, 1: Historia wojskowości, 3-26. [in Polish].

4. Grabarczyk, T. (2000). Piechota zaciężna Królestwa Polskiego w XV w. Łódź. [in Polish].

5. Grabarczyk, T. (2012). Firearms in the equipment of mercenary troop of the Kingdom of Poland in 1471-1500. Fasciculi Archeologiae Historicae, Recent Research into Medieval and Post Medieval Firearms and Artillery, 25, 53-58.

6. Grabarczyk, T. (2015). Jazda zaciężna Królestwa Polskiego. Łódź. [in Polish].

7. Hant, J. \& Carlson, U. (2013). Mercenaries in Medieval and Renaissance Europe. McFarland.

8. Janeczek, A. (2002). New Authority, New Property, New Nobility. The Foundation of Noble Estates in Red Ruthenia during the Fourteenth and Fifteenth Centuries. Quaestiones Medii Aevi Novae, 7, 77-125.

9. Jefferson, J. (2012). The Holy Wars of King Wladislas and Sultan Murad: The Ottoman-Christian Conflict from 1438-1444. Leiden; Boston: Brill.

10. Kaminsky, H. (1967). A History of the Hussite Revolution. Berkeley: University of California Press.

11. Klassen, J. (1978). The nobility and the making of the Hussite Revolution. Boulder, New York: Columbia University Press.

12. Kuras, S. (1983). Stownik historyczno-geograficzny województwa lubelskiego w średniowieczu. Dzieje Lubelszczyzny, 3. Warszawa: Państwowe Wydawnictwo Naukowe. [in Polish].

13. Malinowski, M. (2001). Najnowsza historiografia hiszpańska na temat pogranicza chrześcijańsko-muzułmańskiego na pótwyspie Iberyjskim w XIII-XV w. Acta Universitatis Lodziensis: Folia historica, 72: Studia z historii Polski i powszechnej XIII-XVIII w, 27-41. [in Polish].

14. Pentek, Z. (1997). Polscy uczestnicy wyprawy warneńskiej. Balcanica Posnaniensia, 8, 93-108. [in Polish].

15. Samsonowicz, H. (1992). Rota Piotra Storkowskiego z 1477 r. Acta Universitatis Nicolai Copernici. Historia, 26, (240), 157164. [in Polish].

16. Sułkowska-Kuraś I. \& Kuraś S. (Comps.) (1975). Zbiór dokumentów Matopolskich, VIII. Wrocław; Warszawa; Kraków; Gdańsk: Zakład Narodowy im. Ossolińskich. [in Polish, in Latin].

17. Trelińska, B. (2001). Album armorum nobilium Regni Poloniae XV-XVIII saec. Herby nobilitacji i indygenatów XV-XVIII w. Lublin: Wydawnictwo Uniwersytetu Marii Curie-Skłodowskiej. [in Polish].

18. Tyszkiewicz, J. (1989). Tatarzy na Litwie i w Polsce: Studia z dziejów XIII-XVIII w. Warszawa: Państwowe Wydawnictwo Naukowe. [in Polish] 
Віталій Михайловський

доктор історичних наук, доцент, професор кафедри історії України, Київський університет ім. Б.Грінченка

(Київ, Україна), v.mykhailovskyiakubg.edu.ua ORCID: https://orcid.org/0000-0002-0273-3668

\title{
Подільський плавильний котел: формування мультикультурної шляхетської спільноти на східному кордоні Польського королівства в XV ст.
}

\begin{abstract}
Анотація. Мета дослідження полягає у представленні шляхів формування мультикультурної шляхетської спільноти на території Поділля (від 1434 р. Подільського воєводства), яке була найсхіднішою провінцією Польського королівства. Дослідницька методологія базується на принципах системності та міждисциплінарності. Використано такі загальноісторичні методи: історіографічний, термінологічний, біографічний, просопографічний, генеалогічний та лінґвістичного аналізу. У дослідження на підставі аналізу ймовірних місць походження шляхтичів, що отримували земельні надання на території Подільського воєводства за правління Владислава III у 1434-1444 pр., показано реґіони Польського й Чеського королівств, звідки вони переселялися на східний кордон тогочасної Європи, а саме Малопольща, Мазовія, Великопольща, Моравія, Силезія. Найвіддаленішим місцем, звідки походили ці шляхтичі, були Моравія та Велюнський повіт Серадзького воєводства у Великопольщі. Решта місць походження, які можна локалізувати, віддалені від Поділля на 500-700 км. Для другої половини XV ст. виділено кілька етнічних і соціопрофесійних груп, з яких поповнювалася подільська шляхетська спільнота. Це військові найманці, що походили насамперед із території Чеського королівства, де на той час завершилися Гуситські війни. У середині та другій половині XV ст. більшість із «нових подолян» осіла на Поділлі, а у другому і третьому поколіннях уже вважалися своїми в місцевій шляхетській спільноті. Висновки. З'ясування ймовірних місць походження прибулої у XV ст. на територію Поділля шляхти показує, що походила вона практично з усіх реґіонів Польського королівства. Помітною групою на Поділлі у той час стали військові. Неможливість польського короля забезпечити військо своїми підданими змушувала наймати вихідців із Чеського королівства. Частина з них після завершення служби осідала на Поділлі. Також у той час існувала можливість зміни соціального статусу для міщан, котрі завдяки військовій службі могли стати шляхтичами.
\end{abstract}

Ключові слова: Поділля, шляхта, шляхетська спільнота, прикордоння, Подільське воєводство, найманці. 